\title{
TTR
}

Traduction, terminologie, re?daction

\section{Kathleen Davis. Deconstruction and Translation, (Translation Theories Explained Vol. 8, ed. Anthony Pym), St. Jerome Publishing, Manchester, UK \& Northampton, MA (2001).}

\section{Kaisa Koskinen}

Volume 14, numéro 2, 2e semestre 2001

Antoine Berman aujourd'hui

Antoine Berman for our time

URI : https://id.erudit.org/iderudit/000580ar

DOI : https://doi.org/10.7202/000580ar

Aller au sommaire du numéro

Éditeur(s)

Association canadienne de traductologie

ISSN

0835-8443 (imprimé)

1708-2188 (numérique)

Découvrir la revue

Citer ce compte rendu

Koskinen, K. (2001). Compte rendu de [Kathleen Davis. Deconstruction and Translation, (Translation Theories Explained Vol. 8, ed. Anthony Pym), St. Jerome Publishing, Manchester, UK \& Northampton, MA (2001).] TTR, 14(2), 240-243. https://doi.org/10.7202/000580ar d'utilisation que vous pouvez consulter en ligne. 
Kathleen Davis. Deconstruction and Translation, (Translation Theories Explained Vol. 8, ed. Anthony Pym), St. Jerome Publishing, Manchester, UK \& Northampton, MA (2001).

Deconstruction and Translation, by Kathleen Davis, was published in 2001 as part of the "Translation Theories Explained" series, edited by Anthony Pym. It is a knowledgeable introduction to the ideas of Jacques Derrida, a highly influential and controversial contemporary philosopher. Concentrating on Derrida's early work, it deals explicitly with questions of language and translation. Davis offers a concise and clear account of Derrida's (non)concepts such as différance, iterability and supplementarity, all directly relevant to translation theory. Davis also confronts and clarifies several persistent misunderstandings of Derrida's views, most notably the common suggestion that deconstruction would advocate the notion that "anything goes."

This interpretation of deconstruction as endless freeplay is common among both supporters and opposers of the theory. Deconstruction has been both criticised and celebrated in translation sudies as well, as a rather reckless and pointless activity that implies "bottomless chessboards and random, accidental development, without an end," as "play without calculation, wandering without an end or telos" (Gentzler 1993, pp. 159,167). According to Davis, complete freeplay is precisely what Derrida is not arguing. She draws the reader's attention to the double binds of language: to the stability and instability of meaning, to the similarity and difference that constitute iterability. This leads her to contemplate undecidability and to emphasise translators' responsibility.

I find it easy to agree with Davis' interpretation of (Derridean) deconstruction; it is harder to accept her choice of leaving contributions from translation studies largely undiscussed. According to Davis, in Derrida's later work the emphasis shifts from the question of différance to "that which is excluded and effaced (the "wholly other') in the 'differential' positing of an identity or origin" (p. 91). Subjecting Deconstruction and Translation to a deconstructive analysis in this manner, one cannot help but conclude that for Davis, the sole origin of deconstructionist translation theory is Derrida himself, and that translation studies are the excluded and effaced "wholly other" in her study. Throughout her book, Davis concentrates on Derrida's texts; 
she makes but passing references to translation studies, and no input from any TS scholar is discussed at any length.

"Deconstruction, of course, cannot be considered a translation theory," Davis states in her introduction (p. 2). To a certain extent, I agree: Jacques Derrida is not a translation theorist but a philosopher interested in language and translation. But when his ideas are used to build new approaches to translation within translation studies, in these new contexts deconstruction becomes a translation theory. Given the fact that the book belongs to the series "Translation Theories Explained" I would have expected it to research and "explain" Derrida's influence in translation studies, placing deconstruction in its historical context within TS, illustrating the main ideas within TS, and summarizing the most significant debates within TS. I find it extremely problematic that a volume in the series should put forward a theory which does not even seem to exist in the field of translation studies.

This exclusion of translation theorists could be rooted in the fact that Davis' discussion is claustrophobically English. Her work does not contain a single reference to any texts that are not available in English. This limitation is particularly unfortunate when considering the case of Rosemary Arrojo, a pioneer of deconstruction in translation studies throughout the 1990s. Considering her prominent status in this field, her relative absence in Deconstruction and Translation is striking. Davis includes only three of Arrojo's articles, and the only one discussed in any detail is Arrojo's critique of feminist translation. There is no mention, let alone investigation, of Arrojo's (and other Brazilian scholars') earlier work (from the early 1990s) where she introduces deconstruction to translation theory. They are obviously omitted because they are not in English but originally in Portuguese. While it is a fact of life, however deplorable, that Portuguese is not a major language by today's academic standards, it is more difficult to justify the exclusion of these texts, considering they are also available in German translation (Wolf (ed.), 1997).

Davis is not oblivious to the problems arising from her exclusive "Englishness". She maintains that it "should not be read as privileging English, or American, deconstruction" (p. 68). That is, as far as I can judge, also not the case. Davis builds her discussion on Derrida's own texts, and the American deconstructionism (Yale school) is not dealt with theoretically. It would have been informative 
had the chapter on translating Derrida (into English, naturally) included some discussion of the problematic relationship between French and American deconstruction, and translation's role in it.

The scarcity of English material does not account for the treatment of translation studies scholars' contributions. Even the texts included are only mentioned in passing, and not discussed in detail. The effacement of translation studies throughout the text creates a peculiar feeling of suspense: the writer seems to be withholding information. There are interesting hints towards translation studies, but these implications are undeveloped. In particular, Davis' way of perceiving affinities between deconstruction and Gideon Toury's descriptive approach (p. 41) would have merited expansion. In recent discussions, these two have often been seen as antagonistic and perhaps even irreconcilable research trends. Another interesting line of investigation could have been to discuss the complex relations between deconstruction and feminist and postcolonial translation theories, but this Davis rules out in the very beginning of the book (p. 2).

Since Deconstruction and Translation leaves approaches "sensitive to deconstruction" within translation studies largely undiscussed, logically, it also excludes critical voices from within the field. This has to have been a deliberate choice: one of the most audible critics over the years has been Anthony Pym, editor of the "Translation Theories Explained" series. The list of works cited includes two responses (Arrojo 1996 and Koskinen 1996) to his fiercely critical article but not the article itself (Pym 1995). It would surely have been available, had the author wished to discuss the debate.

Deconstruction and Translation is a useful introduction to Derrida's ideas of language and translation, but when it comes to translation theory it seems to promise more than it delivers. In the introduction, Davis states that she will, "whenever possible," include the work of translation scholars (p. 2). The scarcity of references, then, may appear to verify her claim that "deconstruction itself is strange territory to many translation scholars" (ibid.). I do not think so. Those interested in learning more about how Derrida's ideas have been interpreted and applied within translation studies simply need to seek out other sources. 


\section{Kaisa Koskinen \\ University of Tampere, Finland}

\section{Suggested further readings}

KOSKINEN, Kaisa (2000). Beyond Ambivalence. Postmodernity and the Ethics of Translation. Acta Universitatis Tamperensis 774 (diss.) Tampere, University of Tampere.

PYM, Anthony (1995). "Doubts about Deconstruction as a General Theory of Translation". TradTerm 2, pp. 11-18.

WOLF, Michaela ed. (1997). Übersetzungswissenchaft in Brasilien. Beiträge zum Status von 'Original' und Übersetzung. Tübingen, Stauffenburg.

Francisco Lafarga and Antonio Dominquez (ed.), Los clásicos franceses en el España del siglo XX. Estudios de traducción y recepción, Promociones y Publicaciones Universitarias, Barcelona, 2001, 277 p.

This book presents the proceedings of a conference held at the University of Zaragoza in 1997, the fifth in a series of conferences held throughout the nineties in Spain on the theme of literary and cultural contact between France and Spain. In the foreword to the book, we learn that a research group formed at a University of Barcelona conference in 1988 has been furthering research in the area of translation and comparative literature in Spain, with particular reference to the theme "Images of France in Spanish Literature." While this initiative has produced a number of books focusing on French influence and translations in particular periods of Spanish literary history, most of their publications are wide in scope, covering at least one or several centuries and numerous authors. A full bibliography of these publications is provided.

The multidisciplinary and multilingual nature of the Zaragoza conference on translation of French classics in $20^{\text {th }}$ century Spain is well represented in these published proceedings. Articles appear in Spanish, French and Catalan, and research is rooted in Spanish, Catalan 